\title{
The Comparative Predictive Abilities Of Accrual Earnings And Cash Flows In Periods Of Economic Turbulence: The Case Of The IT Bubble
}

\author{
Marilyn A. Waldron, University of South Australia, Australia
} Charles E. Jordan, University of Southern Mississippi, USA

\begin{abstract}
As set forth in SFAC No. 1, a primary objective of financial reporting is to provide information useful to decision makers. Predicting future cash flows represents a major goal of investors and creditors, and accrual and cash flow accounting information present two alternative factors useful in such predictions. The current research investigates the comparative abilities of accrual basis net income and historical cash flows from operations as predictors of future cash flows during both the economic boom leading up to the IT Bubble and the period of economic duress following the burst of that Bubble. Generally, results indicate that historical cash flows outperform accrual net income in predicting future cash flows during these periods of economic turbulence. Additionally, the evidence reveals great variability in the predictive ability of accrual earnings during the time period studied, suggesting that accrual accounting estimates lose some of their precision during periods of extreme economic fluctuation.
\end{abstract}

Keywords: predicting cash flows, accrual earnings, comparative predictive ability, cash flows

\section{INTRODUCTION}

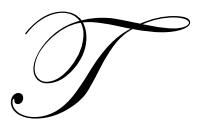

he Financial Accounting Standards Board (FASB) states that a primary purpose of financial reporting is to provide information useful in predicting future cash flows. The FASB further indicates that, relative to historical cash flows, accrual accounting information represents a superior predictor of future cash flows. This is because accrual numbers contain insights about future cash receipts and payments, while historical cash flows lack this forward-looking information. Generally, research results support the FASB's contention concerning the predictive superiority of accruals over cash flows. Even so, a few studies do provide findings of cash flows as a superior predictor, thus resulting in somewhat mixed evidence overall. No prior studies focus on examination of the comparative predictive abilities of accrual income and historical cash flows during a period of extreme economic turbulence.

There is reason to believe that during periods of significant economic uncertainty historical cash flows from operations (CFO) may provide superior predictions relative to accrual earnings. For example, companies experiencing financial problems might try to conceal their financial weaknesses using accrual accounting conventions, thus making the relationship between accrual earnings and future cash flows more tenuous. In addition, as McNichols (2002) notes, the relationship between accrual earnings and future cash flows becomes more complex under uncertain economic conditions because the accrual estimates used in determining net income become more imprecise. As an example, accrual basis sales revenue provides information about future cash collections. During a time of extreme economic turbulence, though, the future collectability of these accrual sales becomes much more uncertain. Although accrual income contains more information than historical cash flows, during a period of economic turbulence the additional information may become more unreliable, thus negatively impacting the ability of accrual earnings to accurately predict future cash flows. 
The current study examines the comparative predictive abilities of accrual earnings and historical cash flows in predicting future cash flows during a period of extreme economic uncertainty (i.e., the period surrounding and including the burst of the IT Bubble) for three industries that have an intrinsic relationship with the IT Bubble (i.e., the information technology (IT), biotechnology, and telecommunications industries). Overall, results show that historical cash flows outperform accrual earnings in the prediction of future cash flows during the time period under study. In addition to providing more accurate predictions relative to accrual earnings, the historical cash flow models also demonstrate consistency from year to year, while significant variability occurs over time in the predictive ability of the accrual earnings models. McNichols (2002) suggests this occurs as a result of accrual earnings becoming a less precise estimator of cash flows as the level of economic uncertainty increases.

\section{LITERATURE REVIEW AND RESEARCH QUESTION}

As an essential question in financial reporting, a number of researchers investigate the comparative usefulness of cash flow versus accrual accounting information in relation to predicting future cash flows. One major decision in the research involves whether to investigate these relationships using a direct or indirect approach. The indirect method uses share prices to proxy for future cash flows (Ball and Brown, 1968; Rayburn, 1986; Wilson, 1986, 1987; Bowen et al., 1987; Ali, 1994; Dechow, 1994; Cheng et al., 1996; Pfieffer et al., 1998; Jordan et al., 2007). Other researchers (Lipe, 1986; Barth et al., 1992; Barth et al., 1999; Barth et al., 2001) note weaknesses in the share price proxy approach for predicting future cash flows and consequently use the direct approach. For example, Barth et al. (2001) state that "share prices fail to reflect accurately the differential persistence of accruals and cash flows (p. 30)." Thus, the present study focuses on the direct approach, which assesses the relationships between historical accrual accounting information and historical cash flows with expected future cash flows.

The argument for using the direct approach is further bolstered by the notion that realized historical cash flows proxy for expected future cash flows (Barth et al., 2001). The underlying conceptual framework for using historical realized cash flows derives from the assumption of rational expectations (McNichols and Wilson, 1988; Penman and Sougiannis, 1998). Prior research results from using the direct approach are mixed, but generally suggest that relative to historical cash flows, accrual earnings are better predictors of future cash flows. Dechow et al. (1998) and Greenberg et al. (1986) demonstrate the superiority of accrual earnings when examining annual data, while Lorek and Willinger (1996) report similarly in relation to predicting quarterly cash flows. Finger (1994) demonstrates that only in the short run do historical cash flows exhibit superior predictions; in the long run, accrual earnings outperform historical cash flows. This is analogous to Bowen et al. (1986), who discuss historical cash flows as not providing significantly better predictions. However, in contrast to the research above and to the FASB's contention, Barth et al. (2001) and Lorek and Willinger (2009) find that cash flows exhibit superior explanatory and predictive power in comparison to that of aggregate accrual earnings.

An accompanying issue addressed in the present study is whether the value relevance of aggregate accrual earnings exhibits a trend in relation to expected future cash flows. Barth et al. (2001) scrutinize individual year-byyear comparative analyses of cash flows and accruals in prediction of future cash flows. Their findings indicate the adjusted $\mathrm{r}^{2}$ of the cash flows model exceeds that of the accrual earnings model in the year-by-year examination of explanatory power. Also examining the comparative predictive abilities of accrual earnings and cash flows over time, Kim and Kross (2005), however, report that contemporaneous earnings provide superior ability compared to historical cash flows in relation to predicting future cash flows. Thus, questions remain concerning not only the relative predictive abilities of accrual earnings and cash flows in a given period, but also in relation to their comparative predictive abilities over time. The present research examines their predictive abilities over time. Yet, the distinguishing feature of the current research lies in the period of time chosen for study.

Penman (2003) argues that generally accepted accounting principles (GAAP) should act as "an anchor during bubbles, to check speculative beliefs (p. 77)." However, some critics suggest that GAAP is not an anchor during turbulent economic times, but that instead GAAP fails users during periods of extreme speculation or duress. Although Penman (2003) admits that GAAP has weaknesses, he notes that accounting standards are not entirely at fault for the failures that occur during extreme economic fluctuations (e.g., the burst of the IT Bubble that occurred around the turn of the millennium). McNichols (2002) indicates that the apparent failures of GAAP-based financial 
statements and in particular accrual basis accounting during the IT Bubble may stem from the fact that the relationship between cash flows and accrual earnings becomes more complex under uncertain economic conditions.

Simply put, during periods of extreme economic fluctuations (i.e., either significant upturns or downturns in the economy), estimates used in accrual basis earnings become much more unreliable than they would be ordinarily. For example, a company that has enjoyed several years of increasing credit sales and strong cash collections on those sales will likely underestimate bad debts on those sales if the company enters a significant downturn. That is, current accounts receivable that ultimately become uncollectible in the future will likely be much more than what was anticipated when accruing bad debts in the present year. Thus, current year's accrual income, which is based partially on the underestimated bad debts expense, will likely be a poor predictor of future cash flows. It is hypothesized in the present study that accrual earnings loses some of its predictive power during periods of extreme economic fluctuations because of the increased uncertainty that occurs in making accrual accounting estimates during these turbulent times. It seems that during these unstable times historical cash flows (which do not rely on accounting estimates) would outperform accrual earnings in the prediction of future cash flows.

To ascertain the relative abilities of accrual earnings and cash flows for predicting future cash flows during periods of extreme economic fluctuation, the current study examines year-by-year results for an 11-year period of time surrounding the IT Bubble. This 11-year time frame includes periods representing the rampant speculation that occurred prior to the IT Bubble, the burst of the Bubble, and the aftermath of the Bubble. Dechow et al. (1998) and Barth et al. (2001) show that general differences exist between the predictive abilities of accrual earnings and cash flows depending on the industry examined. Dechow and Dichev (2002) note that "in the absence of intentional earnings management, accrual quality will be systematically related to ... industry characteristics (p. 36)." For this reason, the current study examines predictions of cash flows for samples of companies within an industry rather than across industries. Because results can vary by industry, three different industries are analyzed for the 11-year period so that results from the study can be viewed as somewhat generalizable. The three industries are the information technology, biotechnology, and telecommunications industries. These particular industries are chosen for study because each one was significantly affected in the IT Bubble. The results provide information for predictions of cash flows at the extremes during an unstable economic time period.

\section{METHODOLOGY}

The main issue under investigation in the present research is the relative ability of historical accrual earnings and historical cash flows to predict future cash flows during periods of economic turbulence (i.e., including both upturns and downturns in the economy). Two simple regression models are used to evaluate the predictive abilities of accrual income and cash flows. The two models are structured as follows:

(1) $\mathrm{CFO}_{\mathrm{i}, \mathrm{t}+1}=\mathrm{a}_{\mathrm{i}, \mathrm{t}}+\mathrm{b}_{\mathrm{i}} \mathrm{NI}_{\mathrm{i}, \mathrm{t}}+\mathrm{e}_{\mathrm{i}, \mathrm{t}}$

(2) $\mathrm{CFO}_{\mathrm{i}, t+1}=\mathrm{a}_{\mathrm{i}, \mathrm{t}}+\mathrm{b}_{\mathrm{i}} \mathrm{CFO}_{\mathrm{i}, \mathrm{t}}+\mathrm{e}_{\mathrm{i}, \mathrm{t}}$

where CFO denotes cash flows from operations, NI symbolizes net income from continuing operations, and $\mathrm{i}$ and $\mathrm{t}$ signify firm and year, respectively, for the 11-year period 1994-2004. CFO derives from its formulation in the statement of cash flows as required by SFAS No. 95 (FASB, 1987). Essentially, the above equations predict CFO in terms of either (1) NI lagged one year or (2) CFO lagged one year. The signs of the coefficients for both the NI and $\mathrm{CFO}$ equations are expected to be positive, as larger (smaller) amounts of either accrual earnings or cash flows in the current period suggest larger (smaller) amounts of cash flows should occur in the next period as well.

Within each of the three industries examined, the initial analysis involves assessing the explanatory power of aggregate accrual earnings (NI) and CFO for the collective time period (1994-2004). This is then followed by a year-by-year investigation of the comparative predictive abilities of the two models. The 11-year time period under study encompasses both a period of significant economic growth, which preceded the IT Bubble, and a period of great economic duress that occurred in the years immediately following the burst of the IT Bubble. Figure 1 provides a graph of the NASDAQ Market Indices for the time period surrounding the IT Bubble. The graph clearly displays the drastic increases in the technology sector occurring prior to the Bubble as well as the significant downturn taking place subsequent to the burst of the Bubble, which occurred around the beginning of the year 2001. 
Figure 1

Graph of NASDAQ Market Indices for the Period of $1992-2005$

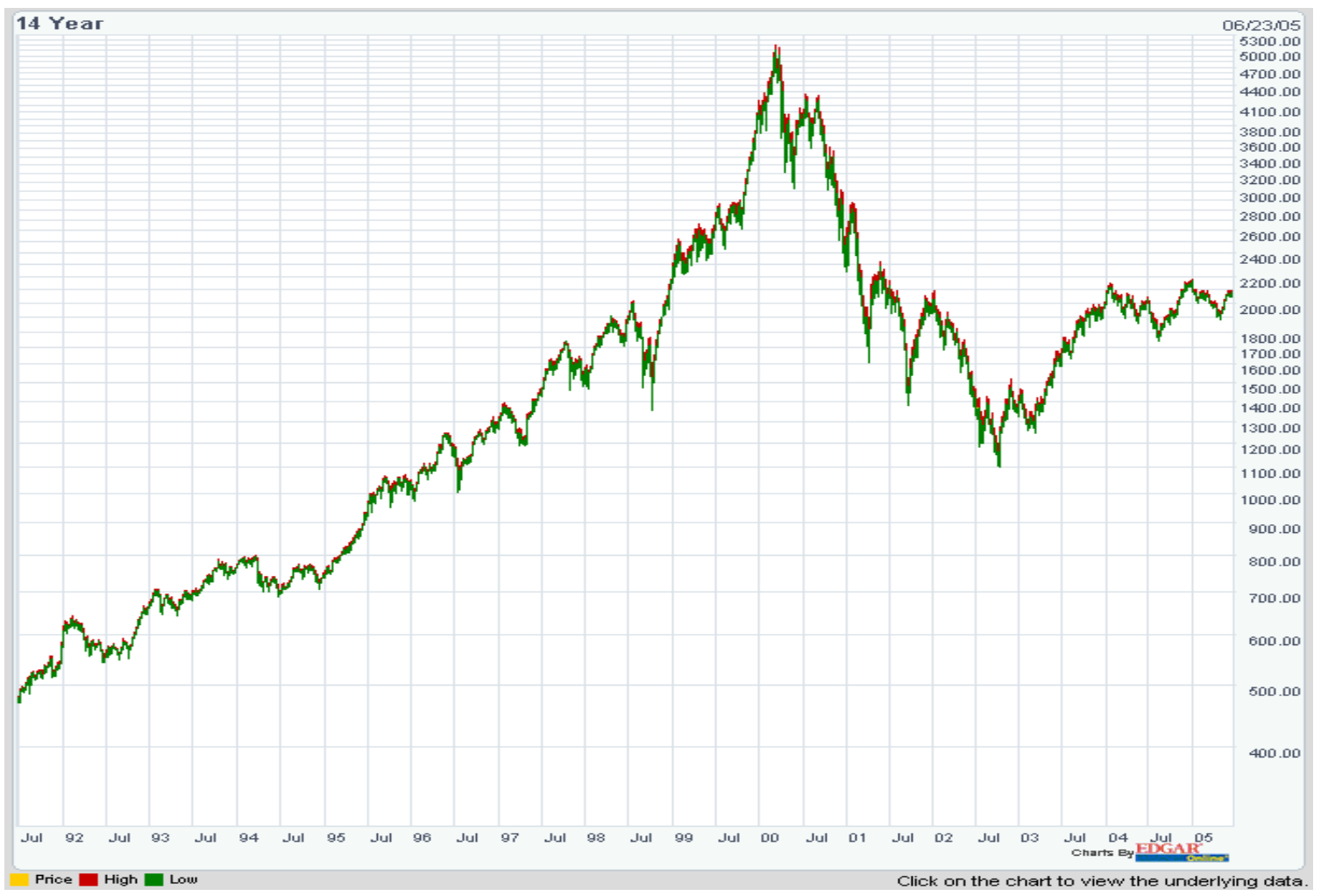

(

Graph adapted from:

\section{NASDAQ Composite}

http://dynamic.nasdaq.com/dynamic/IndexChart.asp?symbol=IXICdesc=NASDAQ+Composite \&sec=nasdaq\&site=nasdaq \&mon ths $=168$.

Cassidy (2002) describes four segments of speculative bubbles, where the first is labelled the "displace" stage, the second a "boom" stage, the third "euphoria" with the final stage a "bust." The four time segments chosen for examination in the present research are selected to emulate these four stages in the form of (1) a pre-IT Bubble "displace" segment (1994-1996), (2) a segment representing the upward trend, or "boom" portion of the Bubble (1997-1999), (3) the euphoria stage in 2000 at the peak, followed by (4) the 'bust' stage displaying its downward trend in the IT Bubble (2001-2002). The final segment represents the post-IT Bubble period (2003-2004).

The application of linear regression to the pair of models initially investigates the comparative explanatory power $\left(r^{2}\right)$ of the two models. Subsequent testing then assesses the comparative predictive abilities of the two models by examining their percentage prediction errors (PPEs). The PPE for an observation is computed as follows: (((Actual CFO - Predicted CFO)/Actual CFO)*100). In essence, the PPE measures the relative size of the error term and represents a simple, yet effective, means of evaluating a model's predictive accuracy. Nonparametric Wilcoxon signed ranks tests are used to evaluate the differences in the predictive abilities (i.e., the PPEs) of the two models. The median PPE for each model is also examined to illustrate the difference in the overall predictive abilities of the two models. Medians are used instead of means because means can be unduly influenced by a few extreme values, especially when analyzing relatively small sample sizes; medians are much less affected by these outlying values and thus are often considered more representative of a group than are means. 
Data are collected from Compustat's annual industrial and research files for all firms with continuing operations during the time period 1994-2004 for the following three industries: IT (SIC 7370-80, 3570-77), biotechnology (SIC 2834-36), and telecommunications (SIC 4813). As noted previously, these three industries are chosen for study because each of them is comprised of technology-based companies that were greatly affected by the IT Bubble. The resulting primary sample of firm-years entails 1,380 firm-years (approximately 125 firms for 11 years) for the IT industry, 1,224 firm-years (approximately 111 companies for 11 years) for the biotechnology industry; and 228 firm-years (approximately 31 firms for 11 years) for the telecommunications industry. Not all of the telecommunications companies existed for all 11 years as some firms were eliminated through mergers in the latter years under study. With only 31 companies, the telecommunications industry represents a relatively small industry, not due to insignificance, but because of its oligopolistic nature.

\section{RESULTS}

\section{Analysis of the IT Industry}

The analysis begins initially with examination of the explanatory power as measured by the adjusted $\mathrm{r}^{2}$ statistic for NI and CFO models developed using pooled data for the IT industry for all 11 years. The key parameters for these two models appear below.

\begin{tabular}{|c|c|c|c|c|}
\hline Model & Coefficient & t-statistic & p-level & Adjusted $r^{2}$ \\
\hline $\mathrm{NI}$ & .157 & 11.016 & .000 & .627 \\
\hline $\mathrm{CFO}$ & .241 & 20.270 & .000 & .944 \\
\hline
\end{tabular}

Both models exhibit high statistical significance with p-levels of .000, and the coefficients display positive signs, as expected. Of particular interest, however, is the relative level of explanatory power for the two models. The adjusted $\mathrm{r}^{2}$ for the NI model suggests that accrual income explains approximately 63 percent of the variation in oneyear-ahead cash flows from operations, while the adjusted $r^{2}$ for the CFO model indicates that historical cash flows explain over 94 percent of the variation in the next year's cash flows.

Continuing the analysis, Table 1 (Panel A) exhibits the adjusted $\mathrm{r}^{2} \mathrm{~s}$ and related statistics for the pair of models year by year for the time period 1994-2004. For each of the 11 years, the CFO model provides a higher adjusted $r^{2}$ than does the NI model. For all years, the adjusted $r^{2}$ for the CFO model exceeds .90 , which indicates that during periods of both economic upturns and downturns historical cash flows explain over 90 percent of the variation in one-year-ahead cash flows. This demonstrates remarkable consistency in the explanatory power of the cash flow models. The NI models demonstrate much greater inconsistency during this time period, ranging from a high adjusted $\mathrm{r}^{2}$ in 1997 (during the upturn period) of .904 to a low in 2002 (during the downturn period) of .553.

Continuing with the IT industry, the analysis next evaluates the comparative predictive abilities of the cash flow and accrual earnings models during the 11-year period under study. As noted previously, the measure of predictive ability used in this project is the PPE, which represents the size of an observation's error term relative to the value of the actual dependent variable. The lower the values of the PPEs produced by a model, the greater is the model's predictive accuracy. Panel B of Table 1 displays an analysis of the NI and CFO models in terms of their comparative predictive abilities. For each year, Panel B shows the number of times the PPE for a given model is less than the PPE for the other model.

For example, for the 114 companies in the sample for 1994, the PPE for the CFO model is smaller than the PPE for the NI model 106 times. Conversely, the PPE for the NI model is less than the PPE for the CFO model for only 8 companies. Panel B also shows a $\mathrm{Z}$ value of -8.976 (with a p-level of .000) for the Wilcoxon signed ranks test for the differences between the PPEs for the two models in 1994. Clearly, in the year 1994, the CFO model outperforms the NI model in terms of predictive accuracy as, relative to the accrual earnings model, the cash flow model produces a lower forecast error for the vast majority of IT companies. Further analysis of Panel B reveals similar results for every year except 1996, when the NI model outperforms the CFO model. For the IT industry, it appears historical cash flows enjoy unambiguous superiority over accrual earnings in terms of predicting one-yearahead cash flows as, relative to the NI models, the CFO models provide lower error terms for 10 of the 11 years. 
Perhaps even more important is that the CFO models exhibit superior predictive ability in the two crucial time periods marked by extreme economic turbulence (i.e., the period of rampant upturn, 1997-2000, and the period of severe downturn, 2001-2002).

Table 1

Regression Statistics and Relative Prediction Accuracy for Models in the IT Industry Year by Year for 1994-2004

\begin{tabular}{|c|c|c|c|c|c|c|c|c|}
\hline \multirow{3}{*}{$\begin{array}{l}\text { Time period } \\
\text { Prior to Bubble: }\end{array}$} & \multirow[b]{2}{*}{$\underline{\text { Model }}$} & \multicolumn{4}{|c|}{ Panel A } & \multicolumn{2}{|c|}{ Panel B } & \multirow[b]{2}{*}{ p-level } \\
\hline & & \multirow[t]{2}{*}{ Coefficient } & t-stat 1 & p-level & \multirow[t]{2}{*}{ Adj. $r^{2}$} & No. of times $^{\mathrm{a}}$ & \multirow[t]{2}{*}{$\underline{Z}$ value $^{\mathrm{b}}$} & \\
\hline & & & & & & & & \multirow{3}{*}{.000} \\
\hline \multirow[t]{2}{*}{1994} & $\mathrm{NI}$ & 1.297 & 18.29 & .000 & .760 & 8 & \multirow[t]{2}{*}{-8.976} & \\
\hline & $\mathrm{CFO}$ & 1.342 & 48.58 & .000 & .954 & 106 & & \\
\hline \multirow[t]{2}{*}{1995} & NI & 2.659 & 17.80 & .000 & .798 & 31 & \multirow[t]{2}{*}{-5.757} & \multirow[t]{2}{*}{.000} \\
\hline & $\mathrm{CFO}$ & 0.909 & 21.26 & .000 & .983 & 84 & & \\
\hline 1996 & $\mathrm{NI}$ & 2.056 & 25.83 & .000 & .854 & 84 & 6.011 & \multirow[t]{2}{*}{.000} \\
\hline & $\mathrm{CFO}$ & 1.015 & 38.36 & .000 & .928 & 31 & & \\
\hline \multicolumn{9}{|c|}{ Upturn of Bubble: } \\
\hline \multirow[t]{2}{*}{1997} & N1 & 1.640 & 32.48 & .000 & .904 & 26 & \multirow[t]{2}{*}{-6.692} & \multirow[t]{2}{*}{.000} \\
\hline & $\mathrm{CFO}$ & 0.940 & 41.92 & .000 & .940 & 86 & & \\
\hline \multirow[t]{2}{*}{1998} & NI & 1.526 & 21.76 & .000 & .807 & 15 & \multirow[t]{2}{*}{-8.693} & \multirow[t]{2}{*}{.000} \\
\hline & $\mathrm{CFO}$ & 1.143 & 36.98 & .000 & .924 & 99 & & \\
\hline \multirow[t]{2}{*}{1999} & NI & 1.769 & 29.57 & .000 & .885 & 14 & \multirow[t]{2}{*}{-8.417} & \multirow[t]{2}{*}{.000} \\
\hline & $\mathrm{CFO}$ & 1.112 & 32.15 & .000 & .901 & 101 & & \\
\hline \multirow[t]{2}{*}{2000} & NI & 1.152 & 24.68 & .000 & .842 & 15 & \multirow[t]{2}{*}{-8.710} & \multirow[t]{2}{*}{.000} \\
\hline & $\mathrm{CFO}$ & 1.172 & 41.39 & .000 & .938 & 100 & & \\
\hline Downturn of $\mathrm{Bu}$ & & & & & & & & \\
\hline 2001 & NI & 1.477 & 31.48 & .000 & .896 & 21 & -8.245 & .000 \\
\hline & $\mathrm{CFO}$ & 1.057 & 34.83 & .000 & .913 & 95 & & \\
\hline 2002 & NI & 1.169 & 11.91 & .000 & .553 & 6 & -9.039 & .000 \\
\hline & $\mathrm{CFO}$ & 1.010 & 56.72 & .000 & .966 & 109 & & \\
\hline Subsequent to B & ble: & & & & & & & \\
\hline 2003 & NI & 2.042 & 21.65 & .000 & .804 & 8 & -9.084 & .000 \\
\hline & $\mathrm{CFO}$ & 1.045 & 71.59 & .000 & .978 & 107 & & \\
\hline 2004 & NI & 1.543 & 25.88 & .000 & .854 & 16 & -8.495 & .000 \\
\hline & $\mathrm{CFO}$ & 1.005 & 70.03 & .000 & .977 & 98 & & \\
\hline
\end{tabular}

${ }^{a}$ Represents the number of times the percentage prediction errors (PPEs) are less than those of the other model.

${ }^{\mathrm{b}} \mathrm{Z}$ value is for a Wilcoxon's signed ranks test for the differences in the PPEs between the NI and CFO models.

Finally, for the IT industry, Figure 2 displays graphically the predictive superiority of the cash flow model relative to the accrual earnings model. For each of the models, the graph presents a line connecting the median PPE on a year-by-year basis. Notice that the line for the median PPEs for the CFO models falls below the line for the NI models every year except 1996. More important, however, is the fact that the line for the median PPEs for the CFO models demonstrates greater consistency than that of the NI models. In particular, the median PPEs for the CFO models remain steadfastly low for all 11 years, while the median PPEs for the NI models display great variability, with significant spikes in 1994, 1998, and 2002. Thus, relative to the NI models, the CFO models display not only greater explanatory power, but also greater consistency over time. 
Figure 2

IT Industry Median PPEs 1994-2004

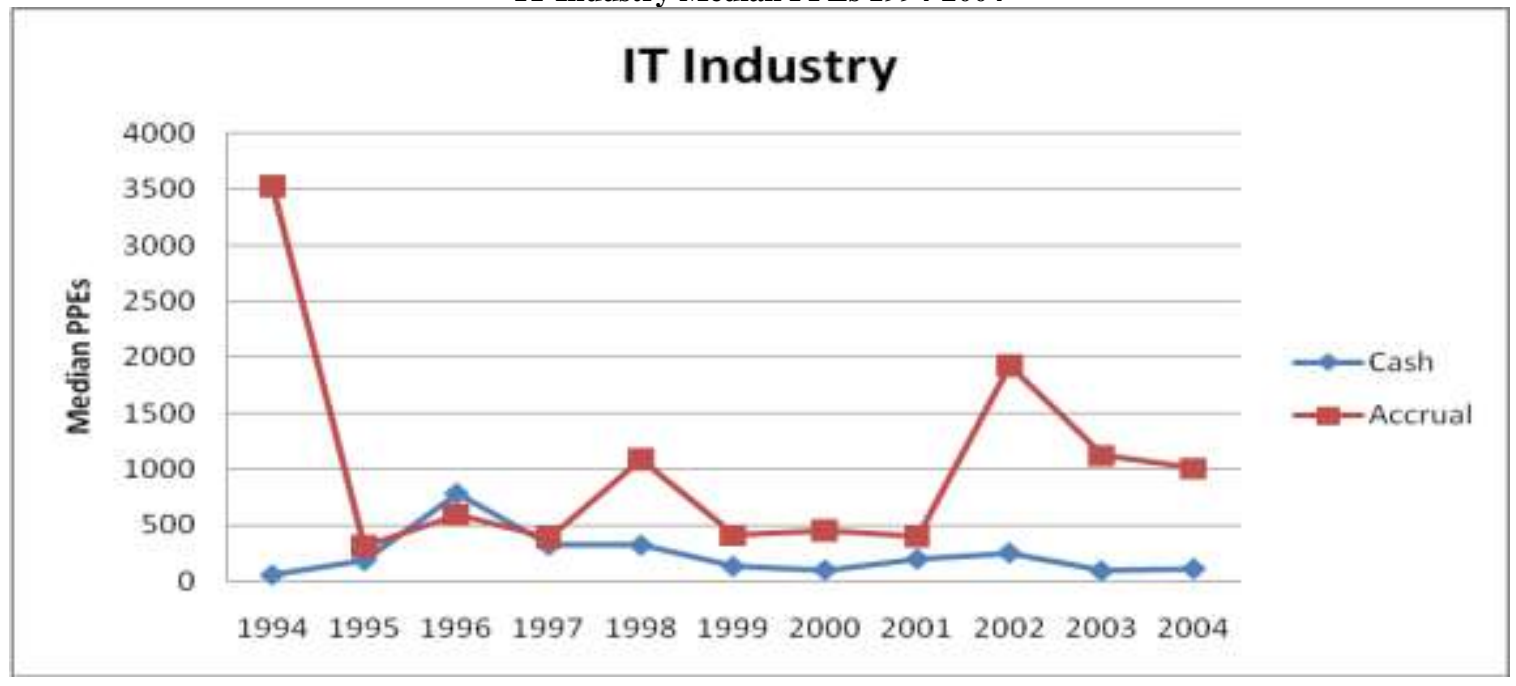

Analysis of the Biotechnology Industry

Analysis of the biotechnology industry proceeds in a manner similar to that of the IT industry. First, an examination of the NI and CFO models is presented based on pooled data for all 11 years. The summary statistics for these two models appear below.

\begin{tabular}{|c|c|c|c|c|}
\hline Model & $\underline{\text { Coefficient }}$ & t-statistic & p-level & Adjusted $\mathrm{r}^{2}$ \\
\hline NI & 1.290 & 64.021 & .000 & .787 \\
\hline $\mathrm{CFO}$ & 1.082 & 102.634 & .000 & .905 \\
\hline
\end{tabular}

Both models produce strong $\mathrm{r}^{2} \mathrm{~s}$ with the NI and CFO models explaining about 79 percent and 91 percent, respectively, of the variation in one-period-ahead cash flows from operations. Like the IT industry previously examined, the advantage in explanatory power within the biotechnology industry lies with the CFO model relative to the NI model. However, the advantage portrayed by the CFO model is not as pronounced in the biotechnology industry as it is in the IT industry. That is, the difference between the adjusted $r^{2} s$ for the two models within the biotechnology industry (i.e., .905 versus .787) is much less than the difference between the $r^{2} s$ for the two models within the IT industry (i.e., 944 versus .627).

For the biotechnology industry, Table 2 (Panel A) shows the summary statistics for NI and CFO models prepared on a year-by-year basis for the 11-year period. Not surprisingly, based on the $\mathrm{r}^{2}$ analysis for the pooled data above, the CFO models produce higher $\mathrm{r}^{2}$ s more frequently than do the NI models. For 8 of the 11 years, the CFO models yield higher $r^{2}$ s. The NI models result in higher $r^{2}$ s for the other three years (i.e., 1995, 1996, and 2002). However, the domination of the CFO models within this industry is not especially robust. In particular, for several of the years, the difference between the $r^{2}$ s of the CFO and NI models is quite small and for all years the $r^{2} s$ for both models are strong.

Panel B of Table 2 presents an analysis of the comparative predictive abilities of the NI and CFO models over time. Interestingly, the CFO models provide lower PPEs than the NI models in 9 of the 11 years; only in 2001 and 2002 do the NI models provide superior predictions (i.e., produce lower PPEs) relative to the CFO models. The p-levels for the Wilcoxon signed ranks test show that the differences in the PPEs each year are significant at a .000 level. The interesting finding from this evidence is that the accrual earnings models outperform the cash flow models in the period of extreme duress (i.e., the downturn of the bubble in 2001 and 2002), but in no other periods. 
Table 2

Regression Statistics and Relative Prediction Accuracy for Models in the Biotechnology Industry Year by Year for 1994-2004

\begin{tabular}{|c|c|c|c|c|c|c|c|c|}
\hline \multirow{2}{*}{ Time period } & \multirow[b]{2}{*}{$\underline{\text { Model }}$} & \multicolumn{4}{|c|}{ Panel A } & \multicolumn{2}{|c|}{ Panel B } & \multirow[b]{2}{*}{ p-level } \\
\hline & & $\underline{\text { Coefficient }}$ & $\underline{\text { t-stat }} 1$ & p-level & $\underline{\text { Adj. } r^{2}}$ & No. of times $^{\mathrm{a}}$ & $\underline{Z}$ value $^{\mathrm{b}}$ & \\
\hline \multicolumn{9}{|l|}{ Prior to Bubble: } \\
\hline \multirow[t]{2}{*}{1994} & NI & 1.530 & 45.59 & .000 & .955 & 21 & -6.958 & .000 \\
\hline & $\mathrm{CFO}$ & 1.180 & 66.12 & .000 & .978 & 77 & & \\
\hline \multirow[t]{2}{*}{1995} & $\mathrm{NI}$ & 1.277 & 46.82 & .000 & .957 & 27 & -5.859 & .000 \\
\hline & $\mathrm{CFO}$ & 0.966 & 45.38 & .000 & .954 & 73 & & \\
\hline \multirow[t]{2}{*}{1996} & NI & 1.388 & 37.25 & .000 & .933 & 25 & -6.041 & .000 \\
\hline & $\mathrm{CFO}$ & 1.193 & 35.36 & .000 & .927 & 75 & & \\
\hline \multicolumn{9}{|c|}{ Upturn of Bubble: } \\
\hline \multirow[t]{2}{*}{1997} & N1 & 1.203 & 33.12 & .000 & .916 & 37 & -3.613 & .000 \\
\hline & CFO & 1.067 & 70.99 & .000 & .981 & 64 & & \\
\hline \multirow[t]{2}{*}{1998} & $\mathrm{NI}$ & 1.064 & 15.99 & .000 & .718 & 7 & -8.474 & .000 \\
\hline & $\mathrm{CFO}$ & 1.026 & 40.59 & .000 & .943 & 94 & & \\
\hline \multirow[t]{2}{*}{1999} & NI & 1.156 & 27.26 & .000 & .881 & 24 & -5.385 & .000 \\
\hline & CFO & 1.074 & 52.11 & .000 & .964 & 77 & & \\
\hline \multirow[t]{2}{*}{2000} & $\mathrm{NI}$ & 1.364 & 22.49 & .000 & .835 & 15 & -8.190 & .000 \\
\hline & $\mathrm{CFO}$ & 1.325 & 25.55 & .000 & .867 & 86 & & \\
\hline \multicolumn{9}{|c|}{ Downturn of Bubble: } \\
\hline \multirow[t]{2}{*}{2001} & $\mathrm{NI}$ & 1.353 & 25.70 & .000 & .868 & 84 & 7.099 & .000 \\
\hline & $\mathrm{CFO}$ & 1.132 & 27.99 & .000 & .887 & 17 & & \\
\hline \multirow[t]{2}{*}{2002} & NI & 1.328 & 31.34 & .000 & .907 & 78 & 6.738 & .000 \\
\hline & $\mathrm{CFO}$ & 0.914 & 23.27 & .000 & .843 & 24 & & \\
\hline \multicolumn{9}{|c|}{ Subsequent to Bubble: } \\
\hline \multirow[t]{2}{*}{2003} & NI & 1.143 & 16.10 & .000 & .719 & 12 & -8.220 & .000 \\
\hline & CFO & 1.089 & 28.58 & .000 & .890 & 90 & & \\
\hline \multirow[t]{2}{*}{2004} & NI & 1.455 & 13.85 & .000 & .654 & 15 & -7.573 & .000 \\
\hline & $\mathrm{CFO}$ & 1.120 & 52.37 & .000 & .964 & 87 & & \\
\hline
\end{tabular}

${ }^{a}$ Represents the number of times the percentage prediction errors (PPEs) are less than those of the other model.

${ }^{\mathrm{b}} \mathrm{Z}$ value is for a Wilcoxon's signed ranks test for the differences in the PPEs between the NI and CFO models.

For the biotechnology industry, Figure 3 provides a graphical analysis of the median PPEs for the NI and CFO models for the 11-year period. For the period of the downturn (i.e., 2001 and 2002), the NI models produce lower median PPEs than the CFO models. For all other years, the CFO models yield lower median PPEs relative to the NI models. However, similar to the results for the IT industry in Figure 2, the lines graphed in Figure 3 for the biotechnology industry demonstrate that the CFO models produce much more consistent predictions from year to year than do the NI models. In particular, the NI models yield spikes on the high side for median PPEs in the years 1998, 2000, and 2003. The CFO models result in no such large deviations in the year-to-year median PPEs.

Overall, results for the biotechnology industry suggest that historical cash flows outperform accrual earnings in the prediction of future cash flows. However, during the very crucial economic downturn immediately following the burst of the IT Bubble (i.e., in 2001 and 2002), accrual earnings appear to have performed better than historical cash flows. There is, of course, no way to determine definitively why this phenomenon occurred. Perhaps managers within this industry made better projections of accrual estimates during this time period because of pressures from the investing public, Congress, and the SEC following the heinous cases of earnings management 
uncovered around the turn of the millennium (e.g., Enron, WorldCom, etc). It is also possible that within this industry other factors explain the behavior.

Figure 3

Biotechnology Industry Median PPEs 1994-2004

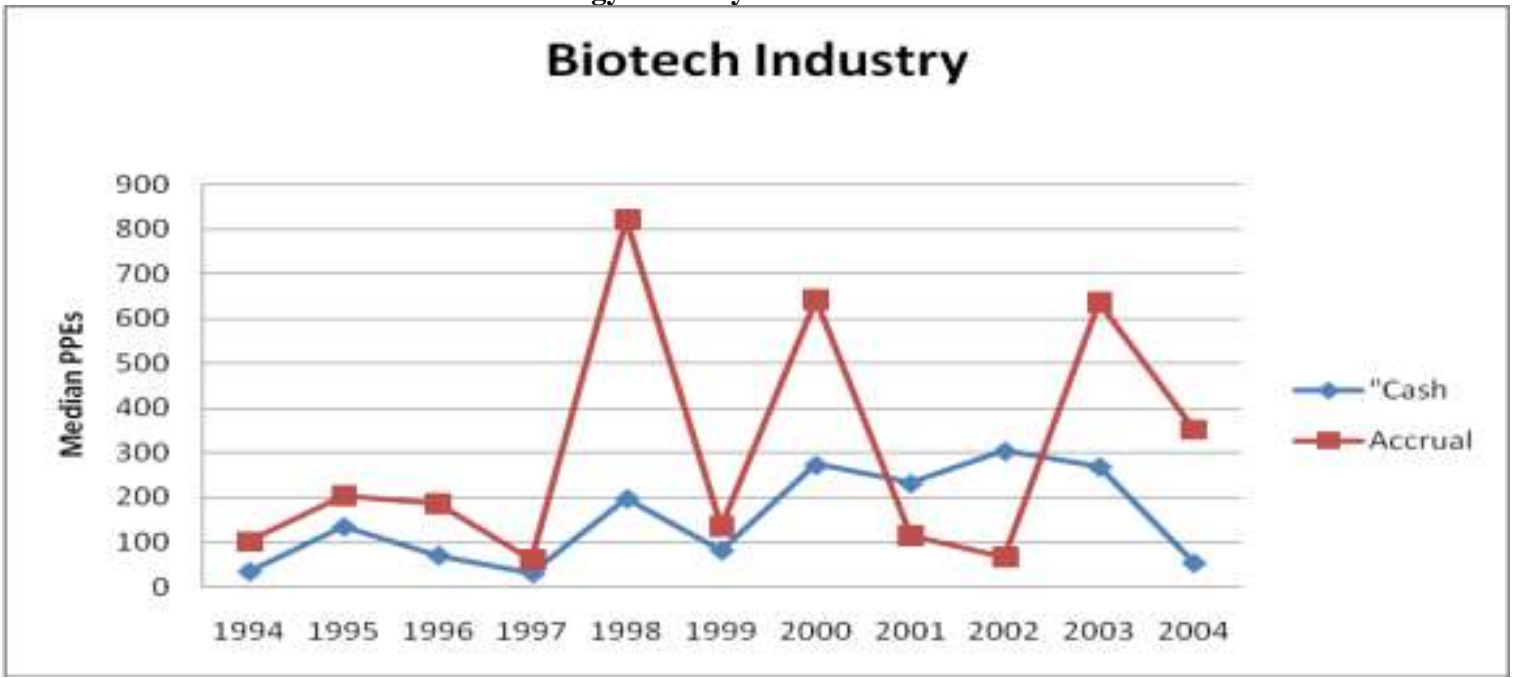

Analysis of the Telecommunications Industry

Compared to the IT and biotechnology industries, the telecommunications industry possesses two distinguishing traits. First, it is a more mature or older industry with many of its companies having been in existence for several decades. Second, it represents a regulated industry with barriers to entry and, thus, is comprised of relatively few companies. However, it too depends heavily on technology and was impacted by the economic turmoil surrounding the IT Bubble. Similar to the two previous industries, analysis of the telecommunications industry begins with an examination of the regression results for the NI and CFO models prepared using pooled data for the entire 11-year period. The summary statistics appear below.

\begin{tabular}{|c|c|c|c|c|}
\hline Model & Coefficient & $\underline{\mathrm{t}-\mathrm{statistic}}$ & p-level & Adjusted $r^{2}$ \\
\hline NI & .652 & 8.714 & .000 & .184 \\
\hline CFO & .995 & 51.264 & .000 & .888 \\
\hline
\end{tabular}

For the telecommunications industry for the period 1994-2004, the cash flow model results in a much larger $\mathrm{r}^{2}$ relative to the accrual earnings model. Historical CFO explains almost 89 percent of the variation in one-year-ahead cash flows, while NI explains only about 18 percent of the variation in expected cash flows.

Panel A of Table 3 provides summary statistics for the year-to-year NI and CFO regression models for the telecommunications industry. For each of the 11 years, the CFO model yields a higher adjusted $\mathrm{r}^{2}$ than does the NI model. In years prior to the Bubble (i.e., in 1994 and 1995), the NI and CFO models produce relatively similar adjusted $r^{2} s$, even though CFO's $r^{2} s$ are somewhat higher. However, as time moves closer to the periods affected by the economic turbulence of the Bubble, the $\mathrm{r}^{2}$ advantage for the CFO models becomes more apparent. For example, in 1999 during the period of economic expansion in the upturn of the Bubble, the CFO and NI models produce $\mathrm{r}^{2} \mathrm{~s}$ of .853 and .393 , respectively. In 2002, during the duress of the downturn in the Bubble, the CFO and NI models yield $\mathrm{r}^{2} \mathrm{~s}$ of .803 and .069 , respectively. Similar results occur in the two years subsequent to the burst of the Bubble (i.e., in 2003 and 2004). 
Table 3

Regression Statistics and Relative Prediction Accuracy for Models in the Telecommunications Industry Year by Year for 1994-2004

\begin{tabular}{|c|c|c|c|c|c|c|c|c|}
\hline \multirow{2}{*}{ Time period } & \multirow[b]{2}{*}{$\underline{\text { Model }}$} & \multicolumn{4}{|c|}{ Panel A } & \multicolumn{3}{|c|}{ Panel B } \\
\hline & & Coefficient & t-stat 1 & p-level & Adj. $r^{2}$ & $\underline{\text { No. of times }}^{\mathrm{a}}$ & $\underline{Z}$ value $^{b}$ & p-level \\
\hline \multicolumn{9}{|l|}{ Prior to Bubble: } \\
\hline \multirow[t]{2}{*}{1994} & NI & 2.217 & 11.66 & .000 & .813 & 8 & -3.684 & .000 \\
\hline & $\mathrm{CFO}$ & 0.998 & 13.09 & .000 & .846 & 24 & & \\
\hline \multirow[t]{2}{*}{1995} & NI & 2.174 & 32.83 & .000 & .971 & 3 & -4.207 & .000 \\
\hline & $\mathrm{CFO}$ & 1.059 & 58.87 & .000 & .991 & 29 & & \\
\hline \multirow[t]{2}{*}{1996} & NI & 2.612 & 6.89 & .000 & .592 & 8 & -3.511 & .000 \\
\hline & $\mathrm{CFO}$ & 0.874 & 18.62 & .000 & .915 & 25 & & \\
\hline \multicolumn{9}{|c|}{ Upturn of Bubble: } \\
\hline \multirow[t]{2}{*}{1997} & N1 & 1.722 & 8.07 & .000 & .667 & 1 & -4.976 & .000 \\
\hline & $\mathrm{CFO}$ & 1.338 & 22.80 & .000 & .942 & 32 & & \\
\hline \multirow[t]{2}{*}{1998} & NI & 2.523 & 11.42 & .000 & .802 & 1 & -4.905 & .000 \\
\hline & $\mathrm{CFO}$ & 1.147 & 29.85 & .000 & .965 & 32 & & \\
\hline \multirow[t]{2}{*}{1999} & NI & 1.794 & 4.66 & .000 & .393 & 4 & -4.690 & .000 \\
\hline & $\mathrm{CFO}$ & 1.296 & 13.64 & .000 & .853 & 29 & & \\
\hline \multirow[t]{2}{*}{2000} & NI & 1.755 & 6.92 & .000 & .594 & 1 & -4.731 & .000 \\
\hline & $\mathrm{CFO}$ & 0.965 & 15.50 & .000 & .885 & 31 & & \\
\hline \multicolumn{9}{|c|}{ Downturn of Bubble: } \\
\hline \multirow[t]{2}{*}{2001} & NI & 1.683 & 11.43 & .000 & .802 & 4 & -4.815 & .000 \\
\hline & $\mathrm{CFO}$ & 1.136 & 39.65 & .000 & .980 & 29 & & \\
\hline \multirow[t]{2}{*}{2002} & NI & 0.444 & 1.69 & .104 & .069 & 5 & -3.568 & .000 \\
\hline & $\mathrm{CFO}$ & 0.852 & 10.14 & .000 & .803 & 21 & & \\
\hline \multicolumn{9}{|c|}{ Subsequent to Bubble: } \\
\hline \multirow[t]{2}{*}{2003} & NI & 0.262 & 1.19 & .247 & .018 & 1 & -4.171 & .000 \\
\hline & $\mathrm{CFO}$ & 0.981 & 17.75 & .000 & .932 & 23 & & \\
\hline \multirow[t]{2}{*}{2004} & NI & 0.126 & 0.51 & .616 & -.041 & 2 & -3.397 & .000 \\
\hline & CFO & 0.898 & 14.32 & .000 & .915 & 18 & & \\
\hline
\end{tabular}

${ }^{a}$ Represents the number of times the percentage prediction errors (PPEs) are less than those of the other model.

${ }^{\mathrm{b}} \mathrm{Z}$ value is for a Wilcoxon's signed ranks test for the differences in the PPEs between the NI and CFO models.

Panel B of Table 3 provides analysis of the relative predictive ability of the two models on a year-by-year basis. Again, for each year, the CFO model outperforms the NI model by producing lower PPEs by an overwhelming margin. For example, in 1995 the CFO model results in a lower PPE than the NI model for 29 of the 32 companies in the sample, while the NI model produces a PPE lower than that of the CFO model for only three firms. Similar results occur every year and the Wilcoxon signed ranks test reveals that the PPEs differ between the two models each year at a significance level of .000.

Figure 4 provides graphs of the median PPEs for the NI and CFO models for the 11-year period. The predictive superiority of the CFO models that appears in Table 3 is confirmed in Figure 4 as the median PPE for the CFO model falls below (i.e., is smaller than) the median PPE for the NI model each year. More important, however, is the consistency that occurs in the predictive ability of the CFO models from year to year relative to the NI models. Figure 4 depicts a small increase in the median PPEs for the CFO models in 2002 and 2003, while all previous years' median PPEs for the CFO models remain relatively low and stable. Relative to the CFO models, the accrual models show much more inconsistency in the values of their year-to-year median PPEs with a very significant upward deviation in 2002 (i.e., during the turbulence of the downturn in the Bubble). 
Figure 4

Telecommunications Industry Median PPEs 1994-2004

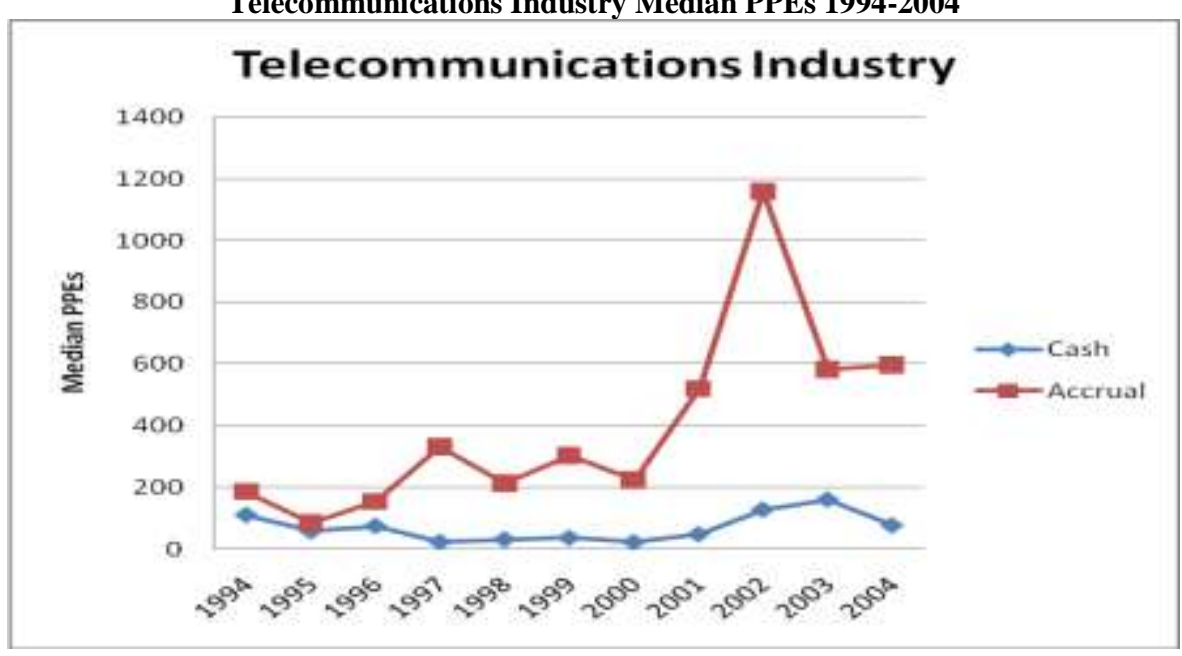

\section{SUMMARY AND CONCLUSION}

In its Conceptual Framework, the FASB notes that a primary purpose of financial reporting is to provide information useful in predicting future cash flows. Additionally, the FASB states that accrual accounting information is more useful than cash basis information in predicting future cash flows. This is because accrual earnings is comprised of numerous estimates that provide information on future cash collections and payments, while historical cash basis information contains little, if any, forward-looking information. The FASB's belief concerning the predictive superiority of accrual basis information relative to historical cash flows has spawned numerous academic studies as researchers attempt to confirm or reject the Board's contention. Generally, these studies support the FASB's belief, as their results indicate accrual earnings outperform historical cash flows in predicting future cash flows (e.g., see Greenburg et al., 1986; Dechow et al., 1998; Lorek and Willinger, 1996). However, a few studies find evidence suggesting just the opposite as, relative to accrual earnings, historical cash flows provide better predictions of future cash flows (e.g., see Barth et al., 2001; Lorek and Willinger, 2009). Thus, the extant literature provides somewhat mixed results concerning the comparative abilities of accrual earnings and historical cash flows in relation to predicting future cash flows.

The present study extends the literature on the comparative predictive abilities of accrual earnings and historical cash flows in predicting future cash flows by examining a period of extreme economic fluctuation. McNichols (2002) notes that the relationship between accrual earnings and cash flows becomes more tenuous during times of economic uncertainty. During such periods, the estimates used in deriving accrual earnings may become less precise, thus weakening the association between accrual earnings and future cash flows. Unlike accrual earnings, though, historical cash flows contain no estimates or judgments about the future, but simply represent descriptive information about the current period's performance. As such, it is hypothesized in the present study that during periods of economic turbulence historical cash flows outperform accrual earnings in predicting future cash flows.

For an 11-year period (i.e., 1994-2004) surrounding the IT Bubble, the comparative abilities of accrual earnings and historical cash flows in predicting future cash flows are examined for three industries significantly affected by the IT Bubble (i.e., the IT, biotechnology, and telecommunications industries). This time period includes the years leading up to the Bubble, which experienced tremendous growth and prosperity, as well as the years immediately following the burst of the Bubble, which are marked by extreme economic duress. In general, results show that historical cash flows outperform accrual earnings in predicting future cash flows in all three industries during these periods of economic turbulence. In addition to providing more accurate predictions of future cash flows relative to the accrual earnings models, the historical cash flow models also provide for greater consistency over time. The accrual earnings models demonstrate great variability in predictive accuracy from year 
to year, which is not surprising given the difficulty in making precise accrual accounting estimates during periods of extreme economic fluctuations.

\section{SUGGESTIONS FOR FUTURE RESEARCH}

The current study examines the comparative predictive abilities of accrual earnings and historical cash flows from operations in predicting future cash flows. However, no attempt is made to evaluate the effects of the individual components comprising accrual earnings and historical cash flows. For example, sales revenue is a major component of accrual earnings. Similarly, cash collections from sales represent a key ingredient in historical cash flows from operations. Prior studies (e.g., see Jordan and Waldron, 2001) indicate these individual components of accrual earnings and historical cash flows provide unique information not captured in models examining aggregate accrual earnings and cash flows from operations. Future research could replicate the current study using the components of accrual earnings and historical cash flows as predictors of future cash flows to ascertain whether these components impact the comparative predictive abilities of accrual versus cash basis information in periods of economic turbulence.

\section{AUTHOR INFORMATION}

Marilyn A. Waldron, CPA (Australia), DBA, earned her doctorate from Louisiana Tech University and is a senior lecturer of accounting in the School of Commerce at the University of South Australia. Dr. Waldron's primary teaching interest is in managerial accounting but her research encompasses a wide range of topics, including management accounting methods, earnings management and business ethics. She has published articles in professional and academic journals, such as Accounting Forum, Journal of Applied Business Research and Oil and Gas Energy Quarterly.

Charles E. Jordan, CPA, DBA, is a professor in the School of Accounting at the University of Southern Mississippi. His primary teaching and research areas are financial reporting. Dr. Jordan has on multiple occasions received the annual BellSouth Outstanding Faculty in the College of Business at the University of Southern Mississippi and was awarded the 2007-2008 Innovation in Applied Research Award for the university. He has published numerous articles in professional and academic journals, including Business Ethics Quarterly, Transportation Journal, Journal of Applied Business Research, Journal of Accountancy, and The CPA Journal.

\section{REFERENCES}

1. Ali, A., The Incremental Information Content of Earnings, Working Capital from Operations, and Cash Flows, Journal of Accounting Research, Vol. 32, No. 1, pp. 61-74, 1994.

2. Ball, R. and P. Brown, An Empirical Evaluation of Accounting Income Numbers, Journal of Accounting Research, Vol. 6, No. 2, pp. 159-178, 1968.

3. Barth, M.E., W.H. Beaver and W.R. Landsman, The Market Valuation Implications of Net Periodic Pension Cost Components, Journal of Accounting and Economics, Vol. 15, No. 1, pp. 27-62, 1992.

4. Barth, M.E., W.H. Beaver, J. Hand and W.R. Landsman, Accruals, Cash Flows and Equity Values, Review of Accounting Studies, Vol. 4, No. 3/4, pp. 205-229, 1999.

5. Barth, M.E., D. Cram and K. Nelson, Accruals and the Prediction of Future Cash Flows, The Accounting Review, Vol. 76, No. 1, pp. 27-58, 2001.

6. Bowen, R., D. Burgstahler and L. Daley, Evidence on the Relationships between Earnings and Various Measures of Cash Flow, The Accounting Review, Vol. 61, No. 4, pp. 713-725, 1986.

7. Bowen, R., D. Burgstahler and L. Daley, The Incremental Information Content of Accruals Versus Cash Flows, The Accounting Review, Vol. 62, No. 4, pp. 723-747, 1987.

8. Cassidy, J., 2002. Dot.Con, The Greatest Story Ever Sold. New York: HarperCollins.

9. Cheng, C., C. Liu and T. Schaefer, Earnings Permanence and the Incremental Information Content of Cash Flows from Operations, Journal of Accounting Research, Vol. 34, No. 1, pp. 173-181, 1996.

10. Dechow, P., Accounting Earnings and Cash Flows as Measures of Firm Performance: The Role of Accounting Accruals, Journal of Accounting and Economics, Vol. 18, No. 1, pp. 3-42, 1994. 
11. Dechow, P., S. Kothari and R. Watts, The Relation between Earnings and Cash Flows, Journal of Accounting and Economics, Vol. 25, No. 2, pp. 133-168, 1998.

12. Dechow, P. and I. Dichev, The Quality of Accruals and Earnings: The Role of Accrual Estimation Errors, The Accounting Review, Vol. 77, No. 4, pp. 35-59, 2002.

13. http://dynamic.nasdaq.com/dynamic/IndexChart.asp?symbol=IXICdesc=NASDAQ+Composite\&sec=nasd aq\&site $=$ nasdaq \&months $=168$.

14. Financial Accounting Standards Board, Objectives of Financial Reporting by Business Enterprises, Statement of Financial Accounting Concepts No. 1, Stamford, CT: FASB, 1978.

15. Financial Accounting Standards Board, Statement of Cash Flow, Statement of Financial Accounting Standards No. 95, Stamford, CT: FASB, 1987.

16. Finger, C., The Ability of Earnings to Predict Future Earnings and Cash Flow, Journal of Accounting Research, Vol. 32, No. 2, pp. 210-223, 1994.

17. Greenberg, R.R., G.L. Johnson and K. Ramesh, Earnings Versus Cash Flow as a Predictor of Future Cash Flow Measures, Journal of Accounting, Auditing and Finance, Vol. 1, No. 4, pp. 266-277, 1986.

18. Jordan, C.E. and M.A. Waldron, Predicting Cash Flow from Operations: Evidence on the Comparative Abilities for a Continuum of Measures, Journal of Applied Business Research, Vol. 17, No. 3, pp. 87-94, 2001.

19. Jordan, C.E., M.A. Waldron, and S.J. Clark, An Analysis of the Comparative Predictive Abilities of Operating Cash Flows, Earnings, and Sales, Journal of Applied Business Research, Vol. 23, No. 3, pp. 53$60,2007$.

20. Kim, K. and W. Kross, The Ability of Earnings to Predict Future Operating Cash Flows Has Been Increasing-Not Decreasing, Journal of Accounting Research, Vol. 43, No. 5, pp. 753-780, 2005.

21. Lipe, R., The Information Contained in the Components of Earnings, Journal of Accounting Research, Vol. 24, No. 3, pp. 37-64, 1986.

22. Lorek, K.S. and G.L. Willinger, A Multivariate Time-series Prediction Model for Cash-flow Data, The Accounting Review, Vol. 71, No. 1, pp. 81-102, 1996.

23. Lorek, K.S. and G.L. Willinger, New Evidence Pertaining to the Prediction of Operating Cash Flows, Review of Quantitative Finance \& Accounting, Vol. 32, No. 1, pp. 1-15, 2009.

24. McNichols, M., Discussion of the Quality of Accruals and Earnings: The Role of Accrual Estimation, The Accounting Review, Vol. 77, No. 4, pp. 61-69, 2002.

25. McNichols M. and G.P. Wilson, Evidence of Earnings Management from the Provision for Bad Debts, Journal of Accounting Research, Vol. 26, No. 3, pp. 1-31, 1988.

26. Penman, S.H., The Quality of Financial Statements: Perspectives from the Recent Stock Market Bubble, Accounting Horizons, Vol. 17, Supplement, pp. 77-96, 2003.

27. Penman, S.H. and T. Sougiannis, A Comparison of Dividend, Cash Flow, and Earnings Approaches to Equity Valuation, Contemporary Accounting Research, Vol. 15, No. 3, pp. 343-383, 1998.

28. Pfieffer, R.J., P.T. Elgers, M.H. Lo and L.L. Rees, Additional Evidence on the Incremental Information Content of Cash Flows and Accruals: The Impact of Errors in Measuring Market Expectations, The Accounting Review, Vol. 73, No. 3, pp. 373-385, 1998.

29. Rayburn, J., The Association of Operating Cash Flow and Accruals with Security Returns, Journal of Accounting Research, Vol. 24, No. 3, pp. 112-133, 1986.

30. Wilson, G.P, The Relative Information Content of Accruals and Cash Flows: Combined Evidence at the Earnings Announcement and Annual Report Release Date, Journal of Accounting Research, Vol. 24, No. 3, pp. 165-200, 1986.

31. Wilson, G.P, The Incremental Information Content of the Accrual and Funds Components of Earnings after Controlling for Earnings, The Accounting Review, Vol. 62, No. 2, pp. 293-322, 1987. 


\section{NOTES}

